\title{
A one-step Laser Process for Rapid Manufacture of Mesoscopic Perovskite Solar Cells Prepared Under High Relative Humidity
}

Dol:

10.1039/C8SE00043C

\section{Document Version}

Accepted author manuscript

Link to publication record in Manchester Research Explorer

Citation for published version (APA):

Chen, Q., Mokhtar, M. Z., Ke, J. C-R., Thomas, A., Hadi, A., Whittaker, E., Curioni, M., \& Liu, Z. (2018). A one-step Laser Process for Rapid Manufacture of Mesoscopic Perovskite Solar Cells Prepared Under High Relative Humidity. Sustainable Energy \& Fuels. https://doi.org/10.1039/C8SE00043C

Published in:

Sustainable Energy \& Fuels

\section{Citing this paper}

Please note that where the full-text provided on Manchester Research Explorer is the Author Accepted Manuscript or Proof version this may differ from the final Published version. If citing, it is advised that you check and use the publisher's definitive version.

\section{General rights}

Copyright and moral rights for the publications made accessible in the Research Explorer are retained by the authors and/or other copyright owners and it is a condition of accessing publications that users recognise and abide by the legal requirements associated with these rights.

\section{Takedown policy}

If you believe that this document breaches copyright please refer to the University of Manchester's Takedown Procedures [http://man.ac.uk/04Y6Bo] or contact uml.scholarlycommunications@manchester.ac.uk providing relevant details, so we can investigate your claim.

\section{OPEN ACCESS}




\section{A one-step Laser Process for Rapid Manufacture of Mesoscopic Perovskite Solar Cells Prepared Under High}

Relative Humidity

Qian Chen ${ }^{\dagger}$, Muhamad Z. Mokhtar ${ }^{\dagger}$, Jack Chun-Ren Ke ${ }^{\ddagger \xi}$, Andrew G. Thomas ${ }^{\dagger \neq}$, Aseel Hadi ${ }^{\dagger}$, Eric Whittaker", Michele Curioni ${ }^{\dagger}$ and Zhu Liu*t

${ }^{\dagger}$ School of Materials, The University of Manchester, Manchester, M13 9PL, UK

Fhoton Science Institute, The University of Manchester, Manchester, M13 9PL, UK.

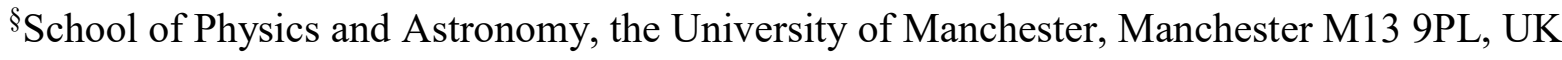

\section{Corresponding Author}

Zhu Liu

Tel.: 00441613064845

*E-mail: zhu.liu@manchester.ac.uk 


\begin{abstract}
Mesoscopic perovskite solar cells (PSCs) containing a $\mathrm{TiO}_{2}$ mesoporous structure and a compact $\mathrm{TiO}_{2}$ film have reached the highest power conversion efficiency (PCE) and excellent stability among various PSC structures. However, conventional fabrication of the mesoscopic structure requires high-temperature heating processes that are considerably time-consuming. Current methods also make it difficult to fabricate integrated or multifunctional devices on the same substrate. Laser processing offers an opportunity to develop a rapid, localized and precise treatment without damaging the substrate or surrounding materials. Here, we demonstrate a rapid and localized one-step fiber laser process to generate both mesoporous and compact $\mathrm{TiO}_{2}$ films on tin-doped indium oxide (ITO) glass. The average PCE obtained for the PSCs by laser irradiation for $1 \mathrm{~min}$, prepared under a high relative humidity of $60 \%$ by a one-step deposition method, is equivalent to that by furnace treatment for $2 \mathrm{~h}$. A fundamental understanding of the laser sintering mechanism using a fiber laser with a wavelength of $1070 \mathrm{~nm}$ has also been established. The use of the fiber laser with a wall-plug efficiency of over $40 \%$ offers an economically feasible, industrially viable solution to the challenge of rapid fabrication of mesoscopic PSCs and integration of multifunctional devices. In addition, it opens a novel route to manufacture tandem, patterned or aesthetic solar cells in the future.
\end{abstract}

Keywords: laser; perovskite solar cell; one-step; rapid manufacture; integration 


\section{Introduction}

The utilization of solar energy, particularly photovoltaic (PV) technology, has been considered as a promising solution to tackle the major challenge of the finite supply of fossil fuels and global environmental issues. ${ }^{[1]}$ Recently, perovskite solar cells (PSCs) have become one of the hottest topics in the field of PV research due to their rapid increases of power conversion efficiency (PCE) beyond $22 \%$ and relatively low fabrication cost. ${ }^{[2-5]}$ Up to date, mesoscopic PSCs comprising of $\mathrm{TiO}_{2}$ mesoporous structure on a compact $\mathrm{TiO}_{2}$ film have achieved highest efficiency and excellent stability among the various structures. ${ }^{[6,7]}$ It has been proved that the use of such $\mathrm{TiO}_{2}$ mesoporous scaffolds contributes to improved charge collection efficiency, less hysteresis and better resistivity to moisture. ${ }^{[8-10]}$

However, fabrication of the $\mathrm{TiO}_{2}$ mesoscopic PSCs requires high temperature processes $\left(>450^{\circ} \mathrm{C}\right)$ and is extremely time consuming. ${ }^{[4,10]}$ Formation of the mesoporous and compact $\mathrm{TiO}_{2}$ films is also performed in a two-step process. Preparation of the $\mathrm{TiO}_{2}$ mesoporous structure is carried out in a furnace at $450-550^{\circ} \mathrm{C}$ for $30 \mathrm{~min}$ to remove the organic binders and achieve sufficient interconnection between the $\mathrm{TiO}_{2}$ nanoparticles, while formation of the compact film also requires a temperature above $450^{\circ} \mathrm{C}$ to transform the $\mathrm{TiO}_{2}$ from an amorphous phase to crystalline form. ${ }^{[4]}$ These long high-temperature processes prevent the high throughput of PSCs, use of flexible substrates, ${ }^{[11]}$ e.g. plastic substrate; and at such temperatures, even glass substrates with large areas could bend irregularly. ${ }^{[12]}$ More importantly, an integral high-temperature heating process by conventional methods also prevents integrating of multifunctional devices on the same substrate. ${ }^{[12]}$ Currently, a number of alternative heating sources have been explored to replace conventional furnace sintering for fabrication of $\mathrm{TiO}_{2}$ mesoporous structures, including UV-irradiation, ${ }^{[13]}$ near infrared (NIR) heating, ${ }^{[14]}$ flame annealing ${ }^{[15]}$ and UV-ozone treatment. ${ }^{[16]}$ 
Lasers, as a state-of-the-art manufacturing tool, enable a local, precise, selective, flexible, non-contact, highly automated, low-cost and scalable fabrication process. ${ }^{[17]}$ They have been used in a number of PSC applications, including laser-assisted growth of perovskite films, ${ }^{[18,19]}$ laser-assisted deposition of $\mathrm{NiO}$ electrode and compact $\mathrm{TiO}_{2}$ films. ${ }^{[20,21]}$ Moreover, in order to scale-up PSC modules for commercialization, laser scribing has been successfully used on isolating transparent conductive oxide (TCO) and other layers of the PSCs with minimal dead areas. $^{[22-24]}$

For laser heat treatment, laser sintering with various wavelengths and pulse widths has been studied in order to form $\mathrm{TiO}_{2}$ mesoporous structure for dye sensitized solar cells (DSSCs). ${ }^{[12,25,26]}$ Compared to conventional furnace or other annealing methods, laser sintering with Nd:YAG lasers shows significant benefits. It allows the integration of DSSCs with different devices on the same substrates, which otherwise could be damaged by furnace sintering. ${ }^{[17]}$ Its local sintering feature can prevent the glass bending induced by conventional heating methods. ${ }^{[12]}$ It also allows the fabrication of $\mathrm{TiO}_{2}$ mesoporous structure on plastic substrates for DSSCs. ${ }^{[25,26]}$ To date, to the best of our knowledge, no work has been reported on the use of laser heat treatment for generation of both mesoporous and compact $\mathrm{TiO}_{2}$ films on TCO-coated glass in one-step.

In this work, we aim to develop a one-step, rapid fabrication technique to generate both mesoporous and compact $\mathrm{TiO}_{2}$ films on ITO-glass using a fiber laser with $1070 \mathrm{~nm}$ wavelength and millisecond pulse width, without thermally damaging the ITO or the glass substrate. Compared to Nd:YAG lasers with wall-plug efficiencies of $2-3 \%,{ }^{[12]}$ used in the studies described above, fiber lasers show a dramatically increased wall-plug efficiency of over $40 \%$. In addition, the millisecond pulse width selected for this work is believed to be essential to produce efficient mesoscopic perovskite solar cells through effective sintering mechanisms for $\mathrm{TiO}_{2}$ mesoporous structure. 


\section{Results and discussion}

Figure 1a illustrates the laser process schematically. Initially, the titanium diisopropoxide bis(acetylacetonate) in 1-butanol and diluted $18 \mathrm{NRT}^{\mathrm{TiO}_{2}}$ paste was spin-coated on the precleaned ITO-glass and dried on the hotplate as described in Experimental Section. When the laser beam irradiated on the sample surface, the $\mathrm{TiO}_{2}$ paste containing $\mathrm{TiO}_{2}$ nanoparticles and the organic binders absorbed the laser beam partially, but a significant amount of the laser beam penetrated through the $\mathrm{TiO}_{2}$ paste, reaching the amorphous compact $\mathrm{TiO}_{2}$ film and the ITO. It was confirmed by the UV-visible spectra as presented in Figure 1b.

To gain insight into the one-step laser process, various samples as described in Fig. 1c were irradiated with the fiber laser beam under the same processing conditions of $107 \mathrm{~W} \mathrm{~cm}^{-2}$ for 60 s, along with temperature monitoring by an IR thermal camera. In order to form an efficient necking of the $\mathrm{TiO}_{2}$ nanoparticles by furnace heating, sintering temperature of at least $450^{\circ} \mathrm{C}$ is normally required. ${ }^{[27]}$ As shown in Figure 1c, the bare glass showed a peak temperature of $433^{\circ} \mathrm{C}$ due to its low photo-thermal conversion. ${ }^{[18,28]}$ For the ITO-glass, the peak temperature was boosted to $584^{\circ} \mathrm{C}$ due to the photon-induced excitation of the free charge carriers in ITO resulting in instantaneous local heating. ${ }^{[28]}$ Adding a thin amorphous compact $\mathrm{TiO}_{2}$ film (50 $\mathrm{nm}$ ) on ITO-glass did not increase the peak temperature. Spin-coating a layer of $\mathrm{TiO}_{2}$ paste $(150 \mathrm{~nm})$ resulted in a peak temperature of $595^{\circ} \mathrm{C}$, due to stronger laser beam absorption of the $\mathrm{TiO}_{2}$ paste as evidence in Figure 1b. This implied that the sintering of the $\mathrm{TiO}_{2}$ paste and the crystallization of the compact $\mathrm{TiO}_{2}$ film were the result of the direct absorption of the laser beam by $\mathrm{TiO}_{2}$ paste, and a sufficient rise of the temperature due to the contribution from the ITO film also enhanced sintering effect and potentially improved adhesion of the compact $\mathrm{TiO}_{2}$ films to the ITO film.

The temperature distribution obtained by the IR thermal camera as shown by the orange area in Figure 1c was uniform across the whole sample surface $(2 \mathrm{~cm} \times 1.5 \mathrm{~cm})$, demonstrating a 
unique feature of the fiber laser process developed in this work. Unlike the commonly used laser spot size of tens of micrometers and the use of a raster scanning to cover entire sample surfaces through overlapping laser tracks for DSSCs, ${ }^{[12,17]}$ the laser beam was defocused to achieve a spot size of $6.9 \mathrm{~cm}^{2}$ (i.e. $2.96 \mathrm{~cm}$ in diameter) in this work. A photograph of the laser processing set-up is shown in Figure S1. The large size of the laser beam offers a unique capability of rapid processing of PSCs to achieve a sintering process without rastering, which overcomes various drawbacks caused by overlapping laser beam tracks, such as re-heating, and reduces processing time in a much simplified manner suitable for practical applications. Although the laser spot size was set to be larger than the sample area of $3 \mathrm{~cm}^{2}$, a mask with customized area or shape could be applied to achieve local sintering of specific area or shape of samples without damaging surrounding areas.

Based on the calculation reported by Mincuzzi et al. on the use of a Nd:YAG laser for DSSCs, processing time $\left(t_{p}\right)$ of $122 \mathrm{~h}$ by a raster laser processing with an average power of 7 $\mathrm{W}$ was required, in comparison of $50 \mathrm{~h}$ and $6.25 \mathrm{~h}$ by a hot-plate and furnace process for sintering of $1 \mathrm{~m}^{2}$ mesoporous $\mathrm{TiO}_{2}$ film. ${ }^{[12]}$ Under the existing laser processing condition in this work, i.e. power density, pulse width and beam dimension, both mesoporous and compact $\mathrm{TiO}_{2}$ films can be locally fabricated on $1 \mathrm{~m}^{2}$ ITO-glass in only $5.56 \mathrm{~h}\left(180 \mathrm{~cm}^{2} \mathrm{~h}^{-1}\right)$. Therefore, this new laser process offers a significant improvement compared to the previously laser work on DSSCs. In addition, the previous work showed that the embodied energy for a Nd:YAG laser with wall plug efficiency of $3.5 \%$ was lower than that of the hot plate, oven and furnace. ${ }^{[12]}$ The fiber laser used in this work has wall-plug efficiency of over $40 \%$. Therefore, the fiber laser process is believed to have a greater potential for industrial applications, than processing using other types of lasers. ${ }^{[12,17,26]}$ 
(a)

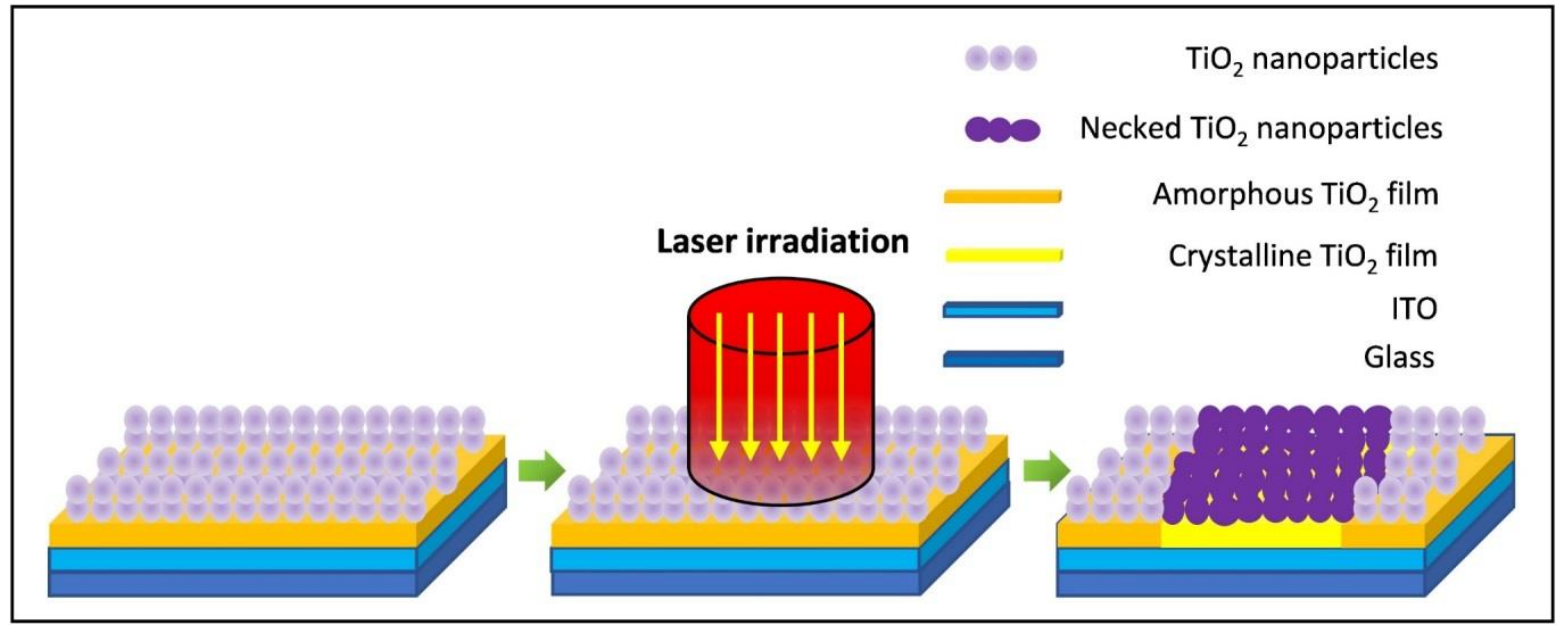

(b)

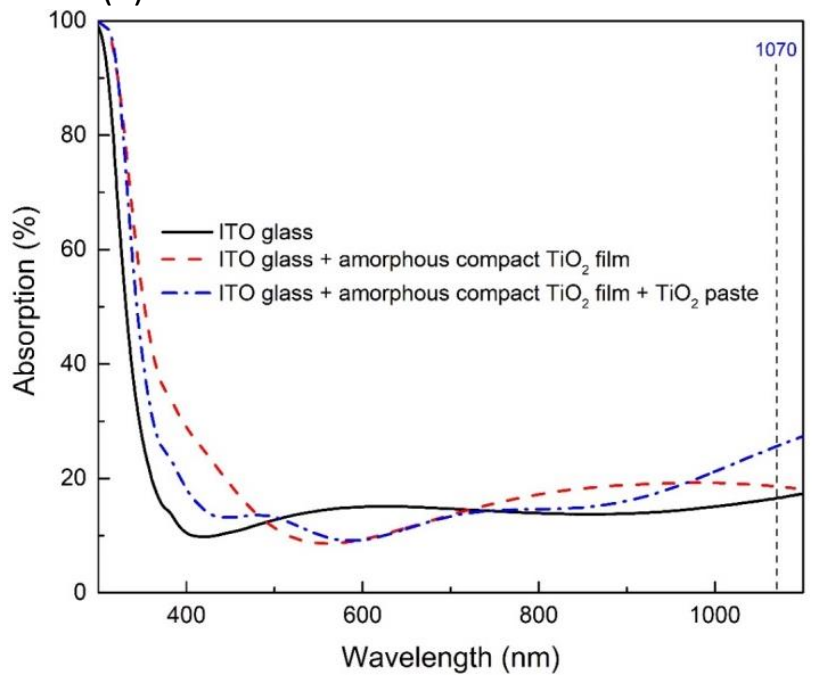

(c)

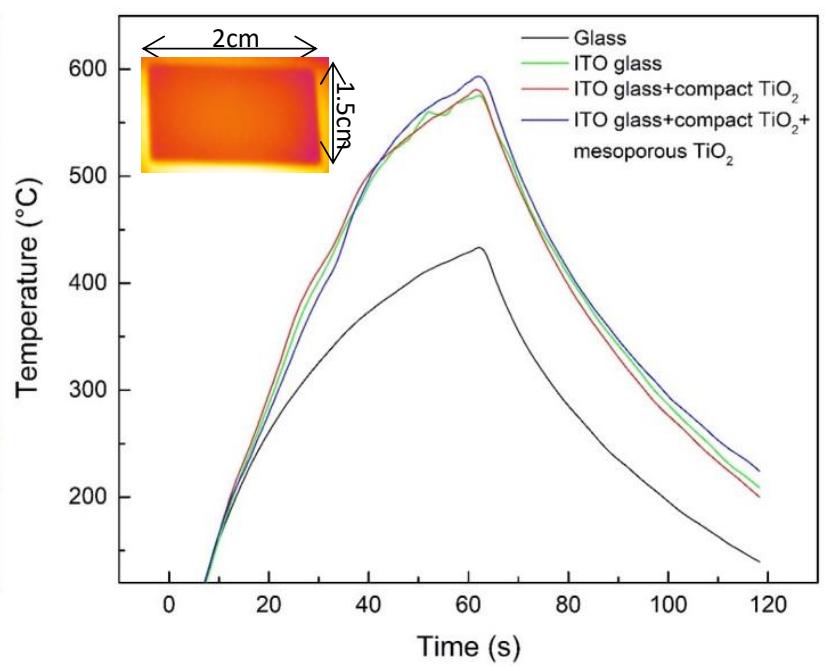

Fig. 1 (a) Schematic representation of laser processing, (b) absorption of ITO-glass and various dried films on the ITO-glass, (c) temperature profiles of various substrates during laser irradiation of $60 \mathrm{~s}$ at $107 \mathrm{~W} \mathrm{~cm}^{-2}$ and temperature distribution of the laser irradiated area recorded with an IR thermal camera.

In the laser process, there are three critical temperatures required to achieve a successful sintering/crystallization of the $\mathrm{TiO}_{2}$ films. For deposited $\mathrm{TiO}_{2}$ paste, a temperature of at least $280^{\circ} \mathrm{C}$ is required to vaporize the organic binder, and $\sim 450^{\circ} \mathrm{C}$ is needed for necking of the $\mathrm{TiO}_{2}$ nanoparticles to take place. ${ }^{[29]}$ For the amorphous compact $\mathrm{TiO}_{2}$ film, a temperature of $450^{\circ} \mathrm{C}$ is essential for crystallization of amorphous $\mathrm{TiO}_{2}$ to occur. Figure 2a presents a comparison of the Raman spectra for the compact $\mathrm{TiO}_{2}$ film obtained by the furnace-, laser- 
treatment at $107 \mathrm{~W} \mathrm{~cm}^{-2}$ and with no treatment. Both the furnace- and laser-treated compact $\mathrm{TiO}_{2}$ films exhibit the peaks at $144 \mathrm{~cm}^{-1}(\mathrm{Eg})^{*}, 399 \mathrm{~cm}^{-1}(\mathrm{~B} 1 \mathrm{~g})^{*}, 519 \mathrm{~cm}^{-1}(\mathrm{~B} 1 \mathrm{~g})^{*}$, and $639 \mathrm{~cm}^{-}$ ${ }^{1}(\mathrm{Eg})^{*}$, corresponding to anatase $\mathrm{TiO}_{2}$ with tetragonal symmetry. ${ }^{[30]}$ This indicates that the laser processing successfully achieved the crystallization of the amorphous compact $\mathrm{TiO}_{2}$ film with no phase transformation to rutile. X-ray diffraction (XRD) patterns of the laser-treated amorphous $\mathrm{TiO}_{2}$ compact film in Figure 2b show the peak at $25.3^{\circ}$ corresponding to (101) anatase phase, as further evidence for crystallization induced by the laser irradiation. Crystallinity of the $\mathrm{TiO}_{2}$ compact film is essential for high performance of PSCs due to the improved charge transport ability and electrical conductivity compared to amorphous phase. ${ }^{[31]}$

(a)

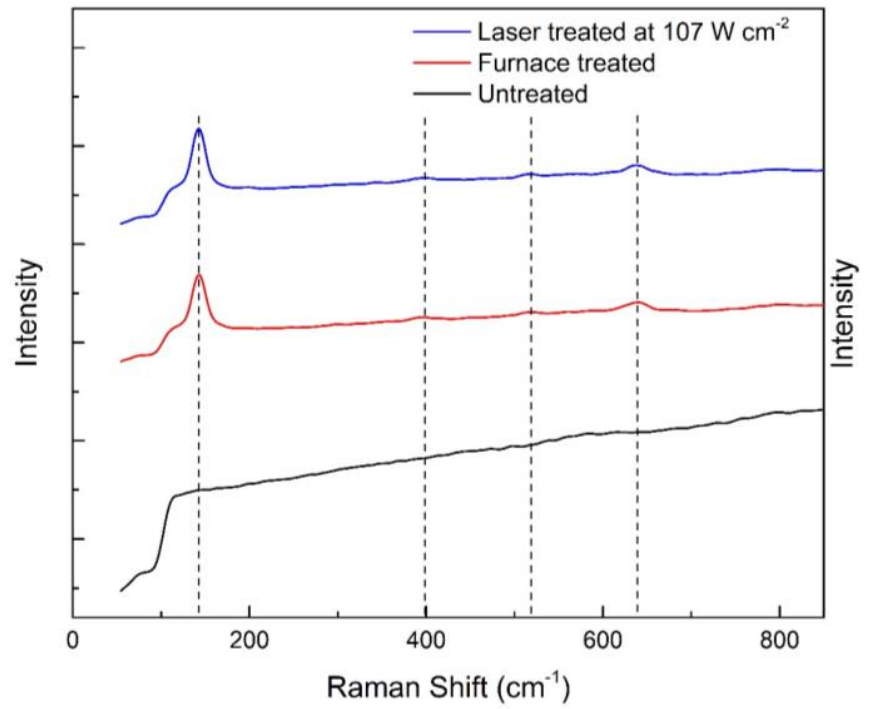

(b)

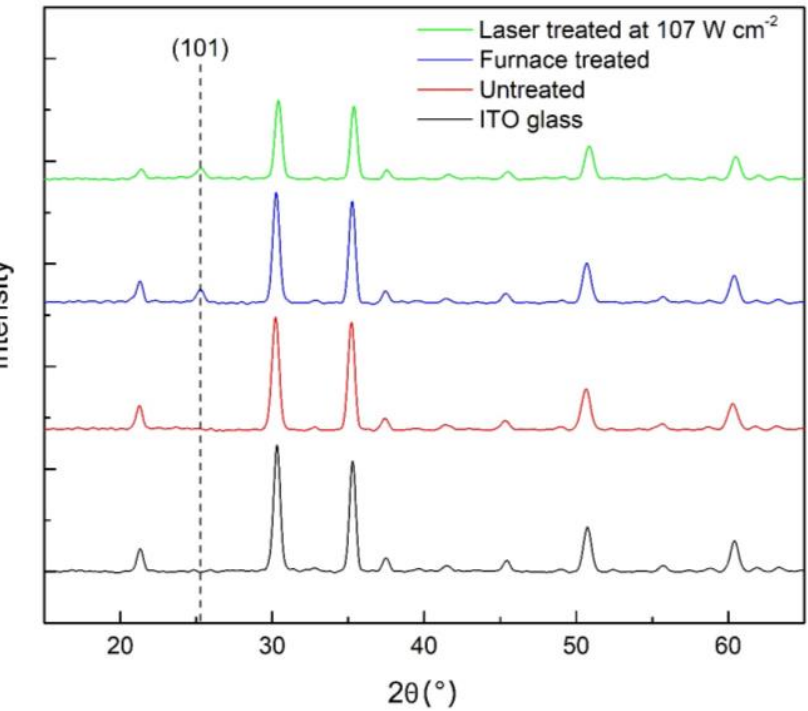

Figure 2. (a) Raman spectra of untreated, furnace- and laser-treated compact $\mathrm{TiO}_{2}$ films at 107 $\mathrm{W} \mathrm{cm} \mathrm{cm}^{-2}$, (b) X-ray diffraction patterns of ITO glass, untreated, furnace- and laser-treated compact $\mathrm{TiO}_{2}$ films at $107 \mathrm{~W} \mathrm{~cm}^{-2}$.

Raman spectra, shown in Figure 3a, were also used to verify the complete removal of the organic binder within the $\mathrm{TiO}_{2}$ paste sintered by the furnace and the laser. The ethyl cellulose organic binder gives rise to Raman peaks at $2876 \mathrm{~cm}^{-1}, 2934 \mathrm{~cm}^{-1}$ and $2976 \mathrm{~cm}^{-1}$ which were completely removed after sintering. ${ }^{[13]}$ Full removal of the organic binder is essential for efficient pore filling and improved electrical conductivity of $\mathrm{TiO}_{2}$ mesoporous structures. ${ }^{[14]}$ Figure 3a also shows that no phase transformation of the anatase $\mathrm{TiO}_{2}$ nanoparticles by laser 
sintering, which is further confirmed by the XRD patterns in Figure 3b. All the samples show the peaks at $25.3^{\circ}, 48.2^{\circ}$ and $55.1^{\circ}$ corresponding to anatase planes at $(101),(200)$ and $(211) .{ }^{[32]}$

(a)

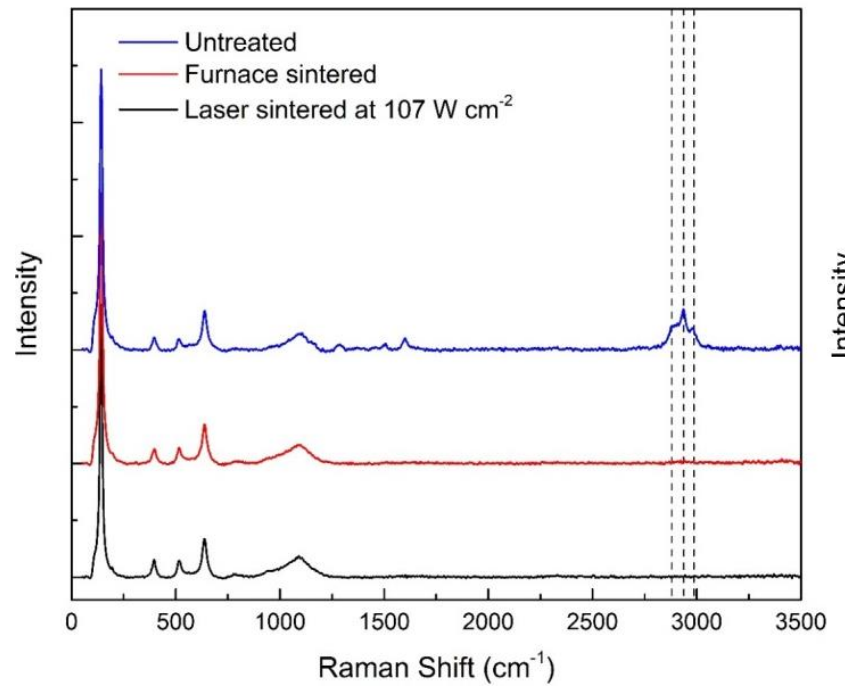

(b)

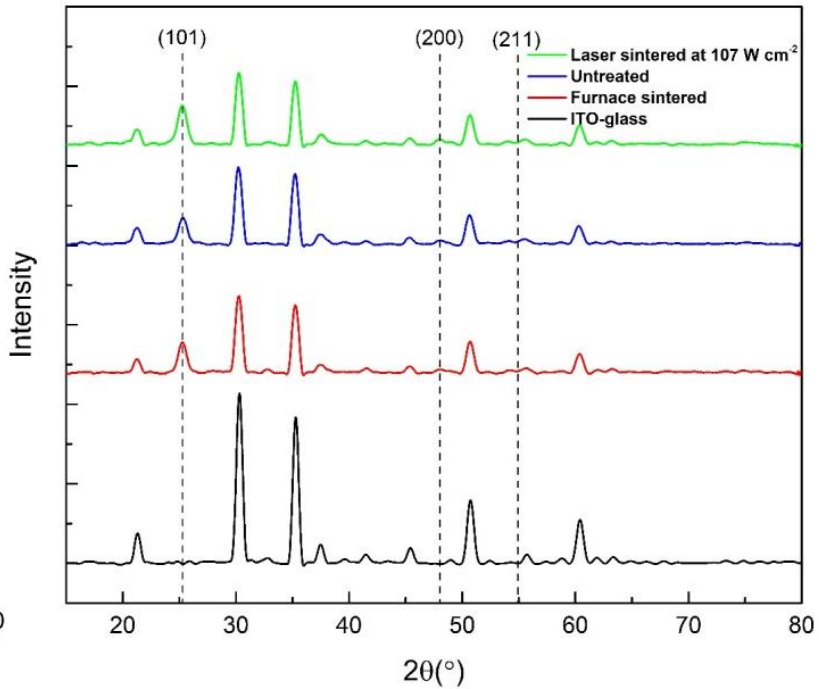

Fig. 3 (a) Raman spectra of untreated, furnace-and laser-treated $\mathrm{TiO}_{2}$ mesoporous structures at $107 \mathrm{~W} \mathrm{~cm}^{-2}$, (b) X-ray diffraction patterns of ITO-glass, untreated, furnace- and laser-treated $\mathrm{TiO}_{2}$ mesoporous structures at $107 \mathrm{~W} \mathrm{~cm}^{-2}$.

Figures 4a, b and c show high-resolution SEM images of the surfaces of the $\mathrm{TiO}_{2}$ mesoporous structures under different conditions. The $\mathrm{TiO}_{2}$ nanoparticles in the untreated film (Figure 4a) were discrete, while the $\mathrm{TiO}_{2}$ mesoporous structure treated by the laser at $107 \mathrm{~W}$ $\mathrm{cm}^{-2}$ (Figure 4c) and furnace (Figure 4b) clearly revealed necking of the $\mathrm{TiO}_{2}$ nanoparticles and consequently increasing in the particle size due to the high temperature sintering. Efficient necking of the nanoparticles is essential to increase the diffusion length of the electrons for high performance PSCs. ${ }^{[27]}$ 


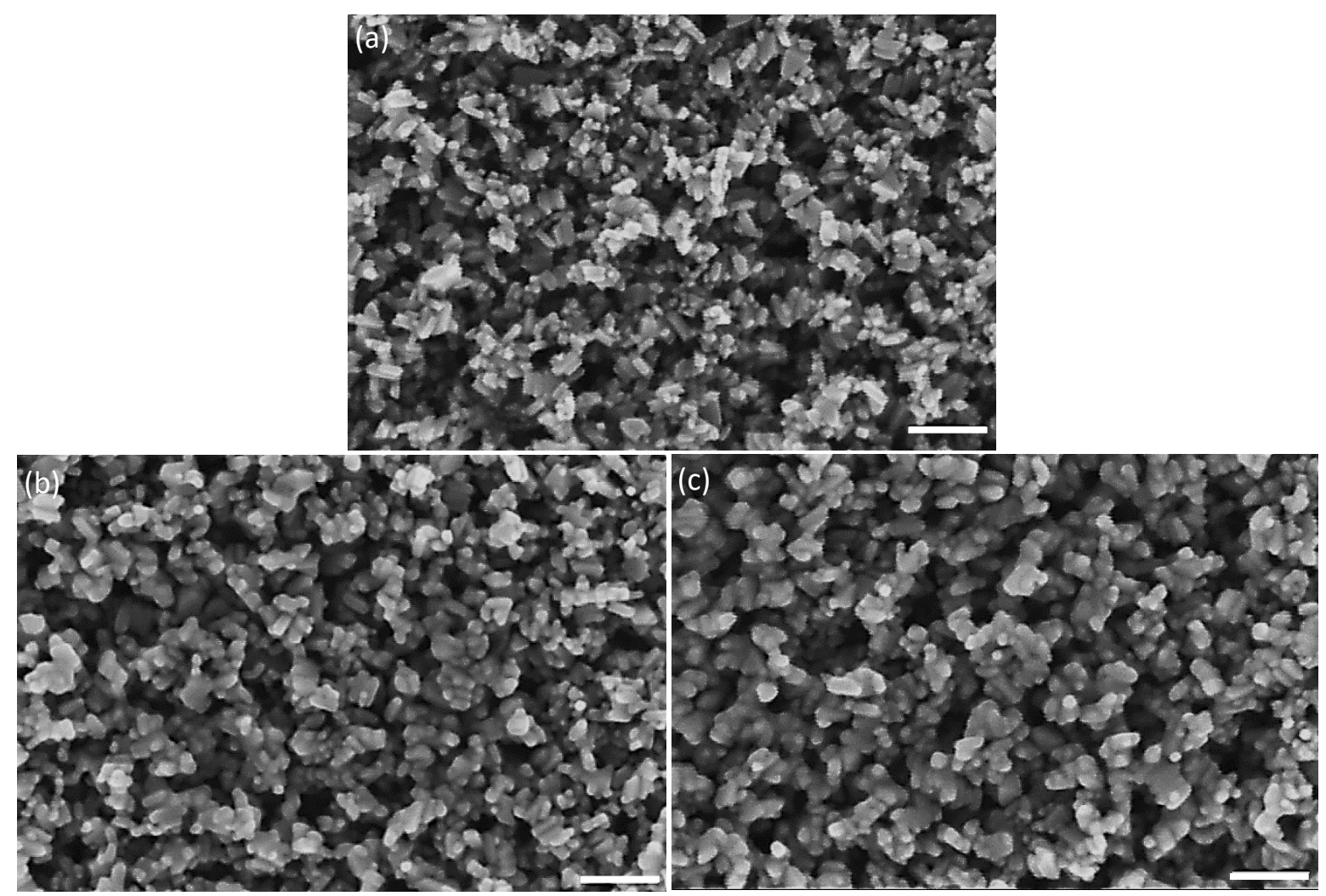

Fig. 4 SEM images of top views of (a) untreated, (b) furnace- and (c) laser-treated $\mathrm{TiO}_{2}$

mesoporous structures at $107 \mathrm{~W} \mathrm{~cm}^{-2}$ (scale bar: $100 \mathrm{~nm}$ ).

The fiber laser process has several advantages over other alternative processes. For example, a recent publication demonstrated an interesting method of using a near infrared (NIR) light to fabricate $\mathrm{mp}-\mathrm{TiO}_{2} / \mathrm{mp}-\mathrm{ZrO}_{2} /$ Carbon structure based perovskite solar cells with a PCE of $11 \%$ within only $30 \mathrm{s.}{ }^{[14]}$ Indeed, the NIR processing is a promising method for rapid manufacturing perovskite solar cells and shows higher throughput than the laser process presented in this work. However, cracking along the standard laser patterned lines (isolating the FTO and glass) with a thickness of $1.4 \mathrm{~mm}$ in width was reported due to the large thermal stress induced by the significant temperature different between the FTO and glass during the rapid NIR process. ${ }^{[14]}$ Therefore, a thinner isolation line of $0.05 \mathrm{~mm}$ was applied to reduce the thermal stress between the glass and FTO during the NIR irradiation. A similar issue was also observed when the fiber laser in continuous-wave mode and shorter irradiating time was applied by the authors. In this work, the formation of cracking was resolved by selecting the pulse-mode with 
a duty cycle of $100 \mathrm{~ms}$ ON/50 ms OFF under the same laser power density. The use of pulsed mode could prolong the period of time for thermal conduction between the glass and ITO, resulting in the reduction of temperature difference between the two layers compared to the continuous mode. Therefore, we have achieved the process without damaging the glass with a laser isolation line up to $2.15 \mathrm{~mm}$. A schematic representation of laser-patterned ITO on glass is shown in Figure S2. We believe that the fibre laser process with the selective pulse widths is a safer approach to conductive oxide coated glass substrate and could be applied to more circumstances for fabrication of PSCs such as aesthetic, patterned or customized cells with different patterned ITO or FTO layer.

In order to determine the quality of the prepared mesoporous and compact $\mathrm{TiO}_{2}$ films with regards to use in PSCs, prototype cells were fabricated. A cross-sectional view of the PSCs fabricated under a relative humidity around $60 \%$ based on a configuration of ITO/cp- $\mathrm{TiO}_{2} / \mathrm{mp}$ $\mathrm{TiO}_{2} /$ perovskite/spiro-OMeTAD/Ag is shown in Figure S3. It has been well documented that a high humidity environment is particularly detrimental to the most commonly used lead-halide based perovskites $\mathrm{CH}_{3} \mathrm{NH}_{3} \mathrm{PbI}_{3}$ and $\mathrm{CH}_{3} \mathrm{NH}_{3} \mathrm{PbI}_{3-\mathrm{x}} \mathrm{Cl}_{\mathrm{x}}$ for solar cell applications. ${ }^{[33,34]} \mathrm{An}$ average PCE of $11 \%$ achieved in the glove box was reduced to $0.35 \%$ in the fabrication environment with humidity over $60 \% .{ }^{[35]}$ To achieve a high PCE, preparation of PSCs is mainly carried out in highly controlled inert atmosphere. ${ }^{[36]}$ The use of inert atmosphere is costineffective which limits the mass-production and applications of PSCs. Although highly efficient PSCs with the PCEs up to $18 \%$ have been recently reported by a two-step deposition method at high relative humidity around $70 \%$, their work also indicated that the device performance by a one-step deposition method was badly affected by the moisture due to the uncontrollable crystallization process in the high humidity condition ${ }^{[37]}$.

In this work, we have adapted the methods reported by Troughton, J. et al. and Ke, W. et al., ${ }^{[36,38]}$ using a one-step deposition method with a molar ratio of $1: 1$ of $\mathrm{PbI}_{2}$ to $\mathrm{CH}_{3} \mathrm{NH}_{3} \mathrm{I}$ and 
adding $5 \% \mathrm{~Pb}(\mathrm{SCN})_{2}$ into the precursor to prepare the perovskite precursor and ethyl acetate as an antisolvent in ambient air with a relative humidity around $60 \%$. It was reported that the use of ethyl acetate as an anti-solvent contributed to a better protection of the MAI-PbI 2 -DMSO intermediate phase during the spin-coating process under the high relative condition, compared to other antisolvents such as chlorobenzene, toluene or diethyl ether, ${ }^{[36]}$ so that an improved photovoltaic performance was achieved due to a better quality of the perovskite layer with less pinholes, defects and variation of the grain sizes treated by ethyl acetate compared to other antisolvents. ${ }^{[36]}$ In addition, a small amount of $\mathrm{Pb}(\mathrm{SCN})_{2}$ additive was also reported to contribute to the increase of grain size of perovskite layer thus an improved photovoltaic performance. $^{[38]}$

Figure 5a shows the $J-V$ curves under simulated solar irradiation of AM $1.5 \mathrm{G}\left(100 \mathrm{~mW} \mathrm{~cm}^{-}\right.$ ${ }^{2}$ ) of the PSCs fabricated with mesoscopic structures treated by the laser at different power densities, compared to a cell where the $\mathrm{TiO}_{2}$ films were treated in a furnace. It was found that increasing the laser power densities from $86 \mathrm{~W} \mathrm{~cm}^{-2}$ to $107 \mathrm{~W} \mathrm{~cm}^{-2}$ remarkably improved the PCE from $4.5 \%$ to $8.8 \%$. Increasing the power density also led to an increase in recorded temperature on the $\mathrm{TiO}_{2}$ surfaces from $513{ }^{\circ} \mathrm{C}$ to $595^{\circ} \mathrm{C}$ as shown in Figure 5b. Following irradiation by the laser pulse the sample was found to remain at a temperature, $\mathrm{T}>450^{\circ} \mathrm{C}$ for $18.9 \mathrm{~s}$ and $39.5 \mathrm{~s}$ and $\mathrm{T}>280^{\circ} \mathrm{C}$ for $66.3 \mathrm{~s}$ and $82.9 \mathrm{~s}$ for the $86 \mathrm{~W} \mathrm{~cm}^{-2}$ and $107 \mathrm{~W} \mathrm{~cm}^{-2}$ pulses, respectively. Since Raman spectra showed that the organic binders were completely removed, and crystallization of the compact $\mathrm{TiO}_{2}$ films occurred for all three laser conditions as shown in Figure S4 and S5, the difference in PCEs is believed to be related to the difference in the degree of interconnections between the $\mathrm{TiO}_{2}$ nanoparticles. As shown in Figure S6, at the higher laser power density, more efficient necking of $\mathrm{TiO}_{2}$ nanoparticles was achieved supporting the correlation between necking and higher PCEs. This is assumed to be linked to longer diffusion lengths of the electrons and fewer recombination reactions. ${ }^{[39]}$ However, with 
a further increase of the laser power density to $115 \mathrm{~W} \mathrm{~cm}^{-2}$, it started to show the signs of superficial melting of the glass which could adversely affect the performance of the devices.

Figure 5. (a) Current density-voltage (J-V) curves of perovskite solar cells produced by $2 \mathrm{~h}$ furnace treatment and laser-treated for 1 min with various power densities under standard AM 1.5G condition, (b) Temperature profiles of ITO glass coated with amorphous compact $\mathrm{TiO}_{2}$ film and $\mathrm{TiO}_{2}$ paste during laser irradiation of $60 \mathrm{~s}$ at 86 and $107 \mathrm{~W} \mathrm{~cm}^{-2}$.
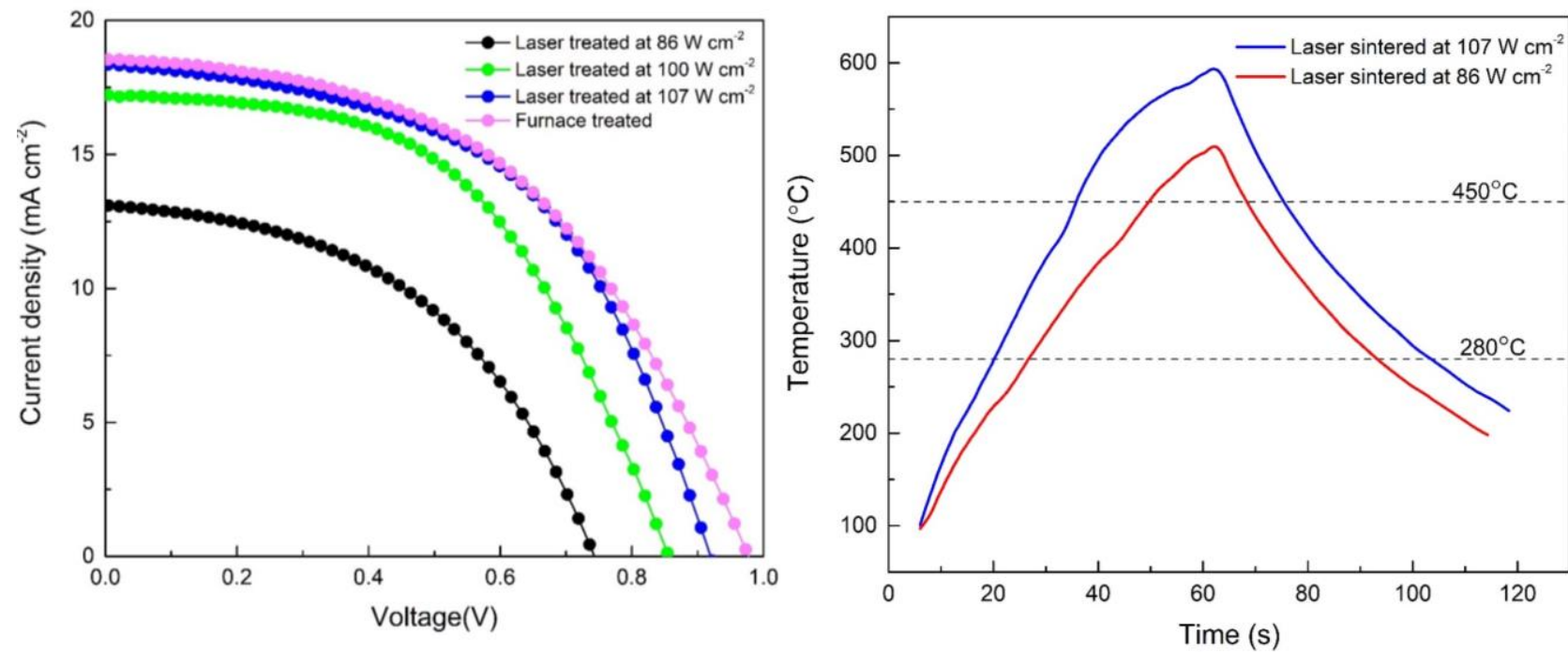

Table 1. Summary of photovoltaic parameters of the perovskite solar cells produced by laser and furnace sintering process at relative humidity around $60 \%$ with a one-step deposition method. Average photovoltaic parameters were calculated based on 6 cells performance.

\begin{tabular}{ccccccc}
\hline \hline Treatment & $\begin{array}{c}\mathrm{V}_{\mathrm{oc}} \\
{[\mathrm{mV}]}\end{array}$ & $\begin{array}{c}\mathrm{J}_{\mathrm{sc}} \\
{\left[\mathrm{mA} \mathrm{cm}^{-2}\right]}\end{array}$ & $\begin{array}{c}\mathrm{FF} \\
{[\%]}\end{array}$ & $\begin{array}{c}\text { PCE best } \\
{[\%]}\end{array}$ & $\begin{array}{c}\text { PCE average } \\
{[\%]}\end{array}$ & $\begin{array}{c}\mathrm{R}_{\mathrm{s}} \\
{\left[\Omega \mathrm{cm}^{2}\right]}\end{array}$ \\
Laser & $904 \pm 23$ & $18.2 \pm 1.6$ & $50.3 \pm 5.8$ & 8.8 & $8.2 \pm 0.5$ & 15.94 \\
& & & & & & \\
Furnace & $960 \pm 12$ & $18.6 \pm 0.4$ & $45.6 \pm 2.3$ & 8.9 & $8.1 \pm 0.5$ & 20.11 \\
\hline \hline
\end{tabular}


Table 1 shows that a maximum PCE of $8.8 \%$, with an average value of $8.2 \%$, was achieved by the optimized laser processing condition of $107 \mathrm{~W} \mathrm{~cm}^{-2}$. This was comparable to the maximum PCE of $8.9 \%$ with an average value of $8.1 \%$ from the furnace process within experimental error. J-V curves with forward and reverse scans for both furnace- and lasertreated samples are shown in Figure S7a and b. It is evident that the J-V curve with forward and reverse scans for the laser-treated sample (Figure S7b) presented a lower hysteresis than that for the furnace-treated (Figure S7a). This could be the result from the smoother and compact $\mathrm{TiO}_{2}$ film with better uniformity and less pinholes fabricated by the laser process (Figure 6b) compared with that by the furnace (Figure 6a). A better quality of the compact $\mathrm{TiO}_{2}$ film is beneficial for a better transport of electrons from the mesoporous $\mathrm{TiO}_{2}$ film infiltrated with the perovskite to the compact film and ITO layer. ${ }^{[40]}$ The photovoltaic performance of the solar cells were relatively stable even with different scan rates as shown in Figure S8. This could, to some extent, indicate that the steady-state power output of the solar cell was relatively close to the $\mathrm{J}-\mathrm{V}$ measurement. ${ }^{[41]}$ The PCEs obtained in in this work with a one-step deposition method at high relative humidity around $60 \%$ were comparable to several recent publications with one-step or even two-step deposition methods. Three examples can be given as follows: 1 ) a two-step method with best PCE of $8.38 \%$ at $60 \%$ humidity. ${ }^{[42]} 2$ ) a onestep method with a best PCE of $8.08 \%$ and an average PCE of $6.68 \%$ at humidity around $40 \%{ }^{[43]} 3$ ) an average PCE of $8.3 \%$ by spay cast method at humidity around $55 \% .^{[44]}$ A detailed chart with more recent publications with the comparable PCEs to our work is shown in Table S1. 

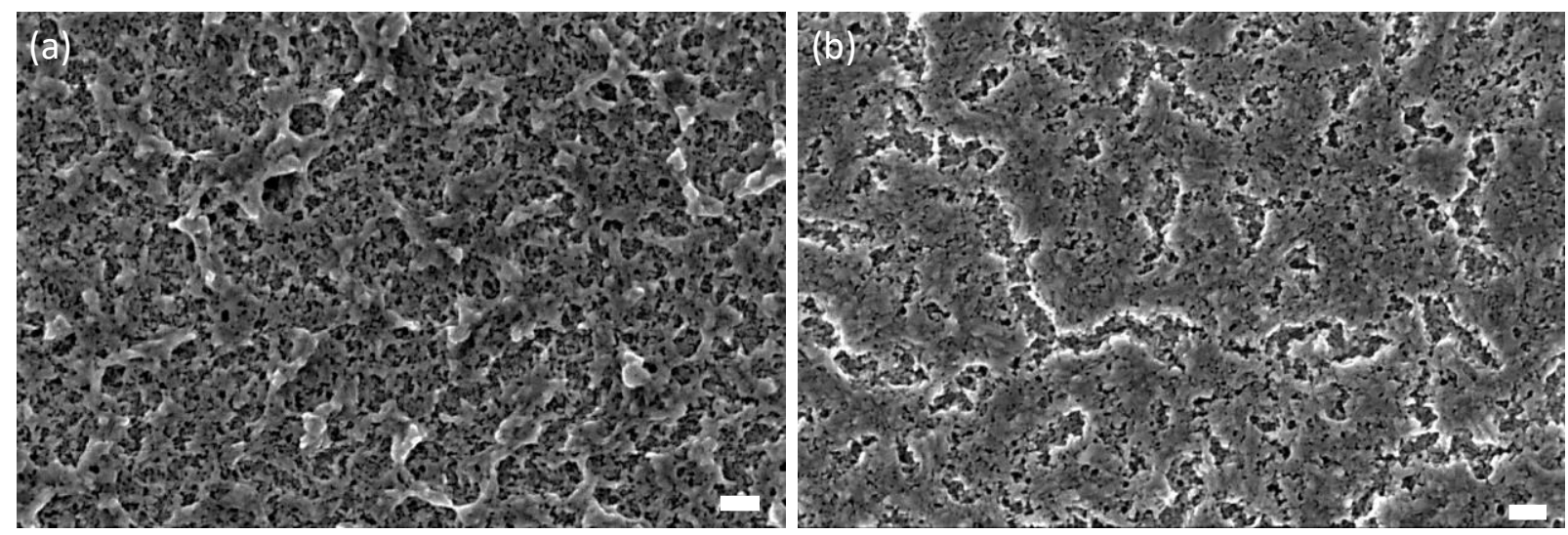

Figure 6. SEM images of top views of (a) furnace- and (b) laser-treated compact $\mathrm{TiO}_{2}$ films at

$107 \mathrm{~W} \mathrm{~cm}^{-2}$ (scale bar: $100 \mathrm{~nm}$ )

Another important observation shown in Table 1 is the difference in fill factors. The PSCs treated at the optimized laser condition show a higher average fill factor of $50.3 \%$ than the furnace-treated with an average of $45.6 \%$. This is more likely to be associated with the observation in Figure 6, where the laser-treated $\mathrm{TiO}_{2}$ film exhibited better uniformity and less pinholes than the furnace-treated one. The smoother compact $\mathrm{TiO}_{2}$ film could contribute to the improved interfacial structure between the compact film and mesoporous film infiltrated with perovskite, thus reduce the recombination sites and increase the charge transport at the interface resulting in an increase of the fill factor. ${ }^{[45,46]}$ Since the laser-treated $\mathrm{TiO}_{2}$ film showed less pinholes and defects, it may also contribute to a better conductivity of the compact film. ${ }^{[40]}$ This is in agreement with the results obtained in our work which the PSCs with the laser-treated had a lower overall series resistance of $15.94 \Omega \mathrm{cm}^{2}$ compared to $20.11 \Omega \mathrm{cm}^{2}$ by the furnacetreated. In addition, it has been reported that the resistivity of ITO increases significantly when a heating process at a temperature above $450^{\circ} \mathrm{C}$ is applied for over $20 \mathrm{~min} .{ }^{[47]}$ Therefore, we believe that another reason for higher series resistance of the furnace-treated devices was the heating process at $>450^{\circ} \mathrm{C}$ for more than $1 \mathrm{~h}$, leading to degradation of the conductivity of the ITO layer. Compared to furnace processes, the heating period for laser process over $450^{\circ} \mathrm{C}$ was only $39.5 \mathrm{~s}$ which caused less degradation of the ITO layer thus also contribute to a lower overall series resistance. The average $V_{\text {oc }}$ of furnace-sintered devices $(960 \pm 12 \mathrm{mV})$, on the 
other hand, was higher than that of the laser-sintered devices $(904 \pm 23 \mathrm{mV})$. This could be attributed to a small amount of $\mathrm{Ti}^{3+}$ present in the furnace-sintered $\mathrm{TiO}_{2}$ mesoporous structure, arising from surface O-vacancies. ${ }^{[48]}$ No $\mathrm{Ti}^{3+}$ was observed in the laser-sintered $\mathrm{TiO}_{2}$ mesoporous structure as shown in the Ti $2 p$ XPS spectra in Figure 7. It has been shown that the electronic defects existed within the $\mathrm{TiO}_{2}$ lattice can be passivated by a small amount of $\mathrm{Ti}^{3+},{ }^{[49]}$ thus resulting a higher $\mathrm{V}_{\mathrm{oc}}$ for the furnace-sintered $\mathrm{TiO}_{2}$ mesoporous structure than that of the laser sintered.

(a)

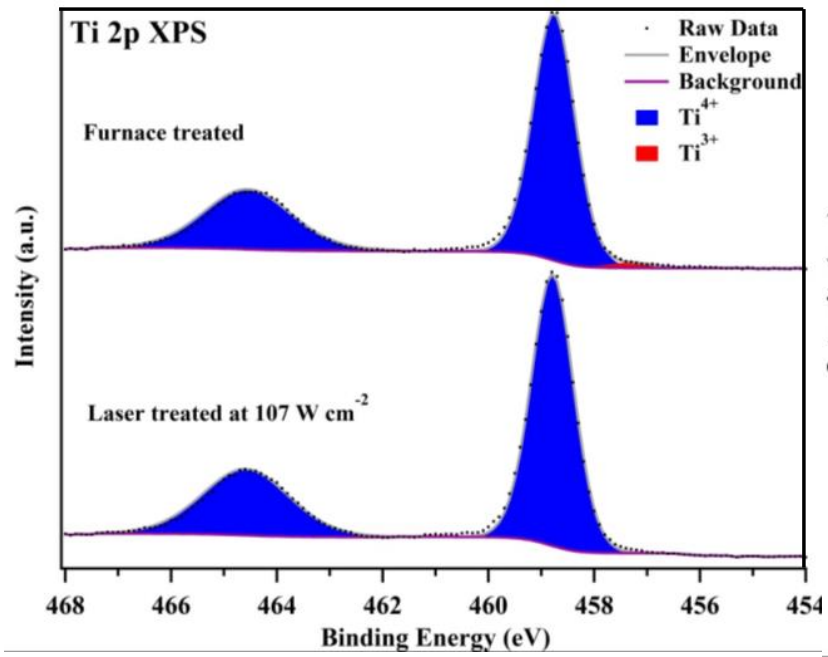

(b)

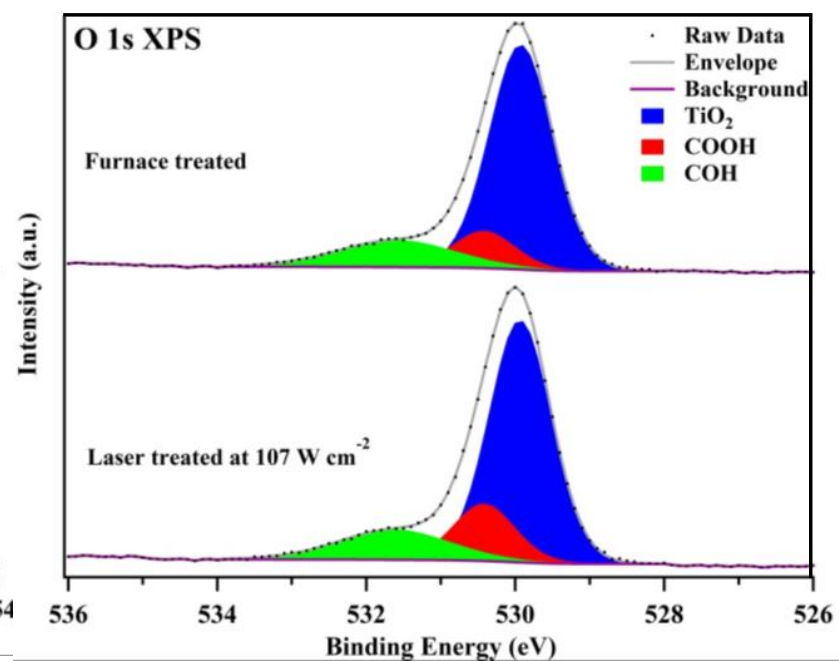

Figure 7. High resolution XPS spectra of (a) Ti 2p and (b) O 1s core levels recorded from the surfaces of the furnace and laser sintered mesoporous $\mathrm{TiO}_{2}$ films at $107 \mathrm{~W} \mathrm{~cm}^{-2}$.

\section{Conclusion}

In summary, we have demonstrated a rapid and localized fabrication technique to generate both mesoporous and compact $\mathrm{TiO}_{2}$ films in one-step for use in perovskite solar cells using a pulsed fiber laser with a wavelength of $1070 \mathrm{~nm}$. With a stationary irradiation of $1 \mathrm{~min}$ at the optimized laser power density, crystallization of the amorphous compact $\mathrm{TiO}_{2}$ film, complete removal of the organic binders and necking of the $\mathrm{TiO}_{2}$ nanoparticles in the mesoporous structure have been successfully achieved. This laser process offers the advantages of localized, a significant reduction of processing time (from $2 \mathrm{~h}$ to $1 \mathrm{~min}$ ), an increase in fill factor and 
decrease of series resistance, over the furnace treatment. In a high relative humidity up to $60 \%$, an average PCE of $8.2 \%$ was achieved in prototype cells using the laser sintered semiconducting oxide support, identical to that produced using a furnace sintering approach. The fiber laser sintering mechanism has also been revealed through the thermal analysis combined with the UV absorption measurements for each individual layer involved in photoanode structure of the PSCs. The use of the fiber laser with over $40 \%$ wall-plug efficiency opens a promising avenue for rapid fabrication of mesoporous and multi-layered metal oxide scaffold perovskite solar cells, as well as the potential for perovskite, dye- and quantum-dot sensitized solar cells fabricated in the form of integrated, multifunctional, tandem, patterned or aesthetic devices.

\section{Experimental Section}

Mesoscopic structure fabrication: ITO-glass substrate (Ossila, $20 \Omega$ sq-1) was cleaned in sequence with $2 \%$ Hellmanex solution in deionized water, acetone, deionized water and then treated by UV-ozone for $15 \mathrm{~min}$. A compact $\mathrm{TiO}_{2}$ layer was prepared by spin coating $0.1 \mathrm{M}$ titanium diisopropoxide bis(acetylacetonate) (75 wt \% in isopropanol, Sigma-Aldrich) solution in 1-butanol (Sigma-Aldrich) at $3000 \mathrm{rpm}$ for $40 \mathrm{~s}$ on the ITO-glass and dried at $125^{\circ} \mathrm{C}$ for 10 min. Then, the same process was repeated with $0.3 \mathrm{M}$ titanium diisopropoxide solution in 1butanol. The ITO-glass with $\mathrm{TiO}_{2}$ precursor was sintered in a furnace with 30 min ramping from room temperature to $500^{\circ} \mathrm{C}$ and kept at $500^{\circ} \mathrm{C}$ for $30 \mathrm{~min}$, followed by natural cooling for 3 hours. Next, Diluted $\mathrm{TiO}_{2}$ paste (Dyesol, 18NR-T) in ethanol at 1:4 by weight was spincoated on the compact $\mathrm{TiO}_{2}$ layer at $4500 \mathrm{rpm}$ for $30 \mathrm{~s}$. The film was dried at $125^{\circ} \mathrm{C}$ for $10 \mathrm{~min}$ and then the same process for sintering compact layer was repeated.

One-step laser fabrication of mesoscopic structure: After the spin coating of $0.1 \mathrm{M}$ and 0.3 $\mathrm{M}$ compact titanium diisopropoxide in 1-butanol and drying at $125^{\circ} \mathrm{C}$ for 10 min, diluted $\mathrm{TiO}_{2}$ paste was spin-coated and dried at the same condition. The substrate was then placed on a 
ceramic plate on the laser work station. An IPG Fiber laser was employed for the sintering process. The laser beam with uniform power density distribution at $86,100,107 \mathrm{~W} \mathrm{~cm}^{-2}$ was applied. A pulse width of $100 \mathrm{~ms}$ with $50 \mathrm{~ms}$ of interval was used. The duration of laser irradiation on the substrate was set to be $1 \mathrm{~min}$. After the laser sintering process, the substrate was cooled down for $90 \mathrm{~s}$ to complete the fabrication process.

Solar cell fabrication: To prepare the perovskite layer, $300 \mathrm{mg} \mathrm{PbI} 2$ (99.9\%, Sigma-Aldrich), $104 \mathrm{mg} \mathrm{CH} \mathrm{CH}_{3} \mathrm{I}\left(98 \%\right.$, Sigma-Aldrich) and $10 \mathrm{mg} \mathrm{Pb}(\mathrm{SCN})_{2}$ (99.9\%, Sigma-Aldrich) was mixed in $600 \mathrm{mg}$ N,N-dimethylformamide (DMF, 99.8\%, Sigma-Aldrich) and $150 \mathrm{mg}$ Dimethyl Sulfoxide (DMSO, 99.9\%, Sigma-Aldrich). The precursor was stirred at room temperature in ambient air for 1 hour. The precursor was spin-coated on the $\mathrm{TiO}_{2}$ mesoporous structure at $4000 \mathrm{rpm}$ for $30 \mathrm{~s}$ and $0.2 \mathrm{ml}$ of ethyl acetate (99.8\%, Sigma-Aldrich) was dripped on the substrate at 8 to $9 \mathrm{~s}$ after the starting of the spin coating process. The film was then heated at $70^{\circ} \mathrm{C}$ for $1 \mathrm{~min}$ and $100^{\circ} \mathrm{C}$ for $10 \mathrm{~min}$ to obtain a $\mathrm{CH}_{3} \mathrm{NH}_{3} \mathrm{PbI}_{3}$ film. To prepare a 2,2',7,7'-tetrakis(N,N-di-4- methoxyphenylamino)-9,9'-spirobifluorene (spiro-OMeTAD, 98\%, Sigma-Aldrich) solution, $40 \mathrm{mg}$ of spiro-OMeTAD was mixed with $10 \mu \mathrm{l}$ bis(trifluoromethane) sulfonamide lithium salt solution $(520 \mathrm{mg} / \mathrm{ml}$ in acetonitrile $)$ and $15 \mu \mathrm{l}$ 4-tert-butyl pyridine in $0.5 \mathrm{ml}$ chlorobenzene (99.8\%, Sigma-Aldrich). The spiro-OMeTAD solution was spin-coated on perovskite layer at $3000 \mathrm{rpm}$ for $30 \mathrm{~s}$. Finally, $80 \mathrm{~nm}$ of Ag was deposited by using thermal evaporator. The average relative humidity in the lab was measured around $70 \%$. A dehumidifier was used to keep a relative humidity of $60 \%$ during the entire fabrication process.

Material and Device Characterization: Morphology of $\mathrm{TiO}_{2}$ mesoporous structures and crosssectional view of the PSC device was characterized by FEG-SEM (ultra 55, Carl Zeiss). A Renishaw Raman Spectroscope with 514 nm excitation Ar+ laser was used to characterize the crystallization of compact $\mathrm{TiO}_{2}$ films and binder evaporation of $\mathrm{TiO}_{2}$ mesoporous structure. A 
Bruker D8 Advance diffractometer $(\mathrm{Cu}-\mathrm{K} \alpha)$ was used to characterize the phase transformation of compact and mesoporous $\mathrm{TiO}_{2}$ films. The surface chemistry of the $\mathrm{TiO}_{2}$ mesoporous structure was characterized by an X-ray Photoelectron Spectroscopy (XPS, Kratos Axis Ultra). The absorption spectrum of ITO-glass and $\mathrm{TiO}_{2}$ paste on ITO-glass was measured by an UVvis spectrophotometer (Shimadzu UV-2401PC). Current density-voltage (J-V) characteristics were measured by a solar simulator (Class AAA, Oriel) with one sun $\left(100 \mathrm{~mW} \mathrm{~cm}^{-2}\right)$ under 1.5G air mass calibrated by NREL certified cell and a Keithley 2420 source meter. A square aperture mask with an area of $0.024 \mathrm{~cm}^{2}$ was used to define the active area. All characterization was performed in an ambient environment with a relative humidity around $60 \%$.

\section{Acknowledgements}

The authors would like to thank Mr. Damian Crosby and Dr. Wei Guo in Laser Processing Research Centre (LPRC) in The University of Manchester for their technical support on laser operations.

\section{Conflict of Interest}

There are no conflicts of interest to declare.

\section{References}

[1] L. K. Ono, N.-G. Park, K. Zhu, W. Huang, Y. Qi, ACS Energy Lett. 2017, 2 (8), 17491751

[2] H. S. Jung, N. G. Park, Perovskite solar cells: From materials to devices. Small 2015, $11,10-25$.

[3] J. Jean, P. R. Brown, R. L. Jaffe, T. Buonassisi, V. Bulović, Energy Environ. Sci. 2015, 8,1200 .

[4] Q. Jiang, L. Zhang, H. Wang, X. Yang, J. Meng, H. Liu, Z. Yin, J. Wu, X. Zhang, J. You, Nat. Energy 2016, 2, 16177.

[5] M. L. Petrus, J. Schlipf, C. Li, T. P. Gujar, N. Giesbrecht, P. Müller-Buschbaum, M. 
Thelakkat, T. Bein, S. Hüttner, P. Docampo, Capturing the Sun: A Review of the Challenges and Perspectives of Perovskite Solar Cells. Adv. Energy Mater. 2017, 7, 1700264.

[6] N.-G. Park, M. Grätzel, T. Miyasaka, K. Zhu, K. Emery, Nat. Energy 2016, 1, 16152.

[7] G. Grancini, C. Roldán-Carmona, I. Zimmermann, E. Mosconi, X. Lee, D. Martineau, S. Narbey, F. Oswald, F. De Angelis, M. Graetzel, M. K. Nazeeruddin, Nat. Commun. 2017, 8,15684 .

[8] Y. Shi, Y. Xing, Y. Li, Q. Dong, K. Wang, Y. Du, X. Bai, S. Wang, Z. Chen, T. Ma, J. Phys. Chem. C 2015, 119, 15868-15873

[9] H. S. Kim, N.-G. Park, J. Phys. Chem. Lett. 2014, 5, 2927-2934.

[10] J. Yang, K. M. Fransishyn, T. L. Kelly, Chem. Mater. 2016, 28, 7344.

[11] F. Di Giacomo, A. Fakharuddin, R. Jose, T. M. Brown, Energy Environ. Sci. 2016, 9, 3007.

[12] G. Mincuzzi, M. Schulz-Ruhtenberg, L. Vesce, A. Reale, A. Di Carlo, A. Gillner, T. M. Brown, Prog. Photovoltaics Res. Appl. 2014, 22, 308.

[13] F. Di Giacomo, V. Zardetto, A. D’Epifanio, S. Pescetelli, F. Matteocci, S. Razza, A. Di Carlo, S. Licoccia, W. M. M. Kessels, M. Creatore, T. M. Brown, Adv. Energy Mater. 2015, 5, 1401808

[14] J. Baker, K. Hooper, S. Meroni, A. Pockett, J. McGettrick, Z. Wei, R. Escalante, G. Oskam, M. Carnie, T. Watson, J. Mater. Chem. A 2017,5, 18643-18650

[15] J. K. Kim, S. U. Chai, Y. Cho, L. Cai, S. J. Kim, S. Park, J. H. Park, X. Zheng, Small $2017,13,1702260$

[16] B. Feleki, G. Bex, R. Andriessen, Y. Galagan, F. Di Giacomo, Mater. Today Commun. $2017,13,232-240$.

[17] G. Mincuzzi, L. Vesce, A. Reale, A. Di Carlo, T. M. Brown, Appl. Phys. Lett. 2009, 
95,103312

[18] M. P. Arciniegas, A. Castelli, S. Piazza, S. Dogan, L. Ceseracciu, R. Krahne, M.

Duocastella, L. Manna, Adv. Funct. Mater. 2017, 27, 1701613

[19] F. Li, W. Zhu, C. Bao, T. Yu, Y. Wang, X. Zhou, Z. Zou, Chem. Commun. 2016,52, 5394-5397.

[20] J. H. Park, J. Seo, S. Park, S. S. Shin, Y. C. Kim, N. J. Jeon, H. W. Shin, T. K. Ahn, J.

H. Noh, S. C. Yoon, C. S. Hwang, S. Il Seok, Adv. Mater. 2015, 27, 4013.

[21] B. Yang, M. Mahjouri-Samani, C. M. Rouleau, D. B. Geohegan, K. Xiao, Phys. Chem. Chem. Phys. 2016,18, 27067-27072.

[22] G. D. Spyropoulos, C. O. Ramirez Quiroz, M. Salvador, Y. Hou, N. Gasparini, P. Schweizer, J. Adams, P. Kubis, N. Li, E. Spiecker, T. Ameri, H.-J. Egelhaaf, C. J. Brabec, Energy Environ. Sci. 2016, 9, 2302.

[23] S. J. Moon, J. H. Yum, L. Lofgren, A. Walter, L. Sansonnens, M. Benkhaira, S. Nicolay, J. Bailat, C. Ballif, IEEE J. Photovoltaics 2015, 5, 1087.

[24] A. Fakharuddin, F. Di Giacomo, A. L. Palma, F. Matteocci, I. Ahmed, S. Razza, A. D’Epifanio, S. Licoccia, J. Ismail, A. Di Carlo, T. M. Brown, R. Jose, ACS Nano 2015, 9, 8420 .

[25] H. Kim, R. C. Y. Auyeung, M. Ollinger, G. P. Kushto, Z. H. Kafafi and A. Piqué, Appl. Phys. A, 2006, 83, 73-76.

[26] H. Pan, S. H. Ko, N. Misra, C. P. Grigoropoulos, Appl. Phys. Lett. 2009, 94.

[27] S. Nakade, M. Matsuda, S. Kambe, Y. Saito, T. Kitamura, T. Sakata, Y. Wada, H. Mori, S. Yanagida, J. Phys. Chem. B 2002, 106, 10004.

[28] T. Jeon, H. M. Jin, S. H. Lee, J. M. Lee, H. Il Park, M. K. Kim, K. J. Lee, B. Shin, S. O. Kim, ACS Nano 2016, 10, 7907.

[29] E. C. Muniz, M. S. G??es, J. J. Silva, J. A. Varela, E. Joanni, R. Parra, P. R. Bueno, 
Ceram. Int. 2011, 37, 1017.

[30] L. Stagi, C. M. Carbonaro, R. Corpino, D. Chiriu, P. C. Ricci, Phys. Status Solidi Basic Res. 2015, 252, 124.

[31] G. Yang, H. Tao, P. Qin, W. Ke, G. Fang, J. Mater. Chem. A 2016, 4, 3970.

[32] S. Sathasivam, D. S. Bhachu, Y. Lu, N. Chadwick, S. A. Althabaiti, A. O. Alyoubi, S. N. Basahel, C. J. Carmalt, I. P. Parkin, Sci. Rep. 2015, 5, 10952.

[33] Q. Tai, P. You, H. Sang, Z. Liu, C. Hu, H. L. W. Chan, F. Yan, Nat. Commun. 2016, 7, 11105.

[34] J. Chun-Ren Ke, A. S. Walton, D. J. Lewis, A. Tedstone, P. O’Brien, A. G. Thomas, W. R. Flavell, Chem. Commun. 2017, 53, 5231.

[35] Z. Yang, C. C. Chueh, F. Zuo, J. H. Kim, P. W. Liang, A. K. Y. Jen, Adv. Energy Mater. 2015, 5 .

[36] J. Troughton, K. Hooper, T. M. Watson, Nano Energy 2015, 5, 1500328.

[37] Y. Cheng, X. Xu, Y. Xie, H.-W. Li, J. Qing, C. Ma, C.-S. Lee, F. So, S.-W. Tsang, Sol. RRL 2017, 1700097.

[38] W. Ke, C. Xiao, C. Wang, B. Saparov, H. S. Duan, D. Zhao, Z. Xiao, P. Schulz, S. P. Harvey, W. Liao, W. Meng, Y. Yu, A. J. Cimaroli, C. S. Jiang, K. Zhu, M. Al-Jassim, G. Fang, D. B. Mitzi, Y. Yan, Adv. Mater. 2016, 28, 5214.

[39] D. Zhao, T. Peng, L. Lu, P. Cai, P. Jiang, Z. Bian, J. Phys. Chem. C 2008, 112, 8486.

[40] C. Huang, C. Liu, Y. Di, W. Li, F. Liu, L. Jiang, J. Li, X. Hao, H. Huang, ACS Appl. Mater. Interfaces 2016, acsami.6b00846.

[41] J. A. Christians, J. S. Manser, P. V. Kamat, Best practices in perovskite solar cell efficiency measurements. Avoiding the error of Making Bad Cells Look Good. $J$. Phys. Chem. Lett. 2016, 8, 8520-8526.

[42] G. Murugadoss, H. Kanda, S. Tanaka, H. Nishino, S. Ito, H. Imahoric, T. Umeyama, J. 
Power Sources 2016, 307, 891.

[43] S. Prathapani, V. More, S. Bohm, P. Bhargava, A. Yella, S. Mallick, Appl. Mater. Today 2017, 7, 112-119.

[44] D. K. Mohamad, J. Griffin, C. Bracher, A. T. Barrows, D. G. Lidzey, Adv. Energy Mater. 2016, 6, 1600994.

[45] B. Conings, L. Baeten, T. Jacobs, R. Dera, J. D’Haen, J. Manca, H. G. Boyen, APL Mater. 2014, 2, 081505

[46] Z. Liu, Q. Chen, Z. Hong, H. Zhou, X. Xu, N. De Marco, P. Sun, Z. Zhao, Y.-B. Cheng and Y. Yang, ACS Appl. Mater. Interfaces, 2016, 8, 11076-11083.

[47] W. L. Hsu, Y. H. Pai, F. S. Meng, C. W. Liu, G. R. Lin, Appl. Phys. Lett. 2009, 94, 231906

[48] M. J. Jackman, A. G. Thomas, C. Muryn, J. Phys. Chem. C 2015, 119, 13682.

[49] F. Giordano, A. Abate, J. Pablo, C. Baena, M. Saliba, T. Matsui, S. H. Im, S. M. Zakeeruddin, M. K. Nazeeruddin, A. Hagfeldt, M. Graetzel, Nat. Commun. 2016, 7, 10379. 


\section{Table of contents}

A one-step laser process is applied to fabricate mesoporous and compact $\mathrm{TiO}_{2}$ films in $1 \mathrm{~min}$ for perovskite solar cells.

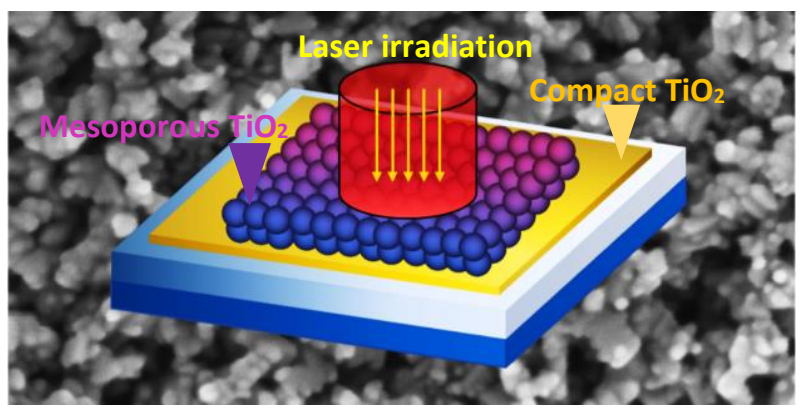

